\section{The pollen record and Easter Island statues}

THE recent pollen study of Easter Island by Flenley and King ${ }^{1}$ is very welcome. However, we must express reservations about their tentative conclusions that deforestation occurred on the island well after the arrival of man and that it caused the cessation of the monolithic statue building. There is a general assumption, which can be traced to La Pérouse ${ }^{2}$, that large timbers, obtained from former tall forests, must have been required to transport the statues ${ }^{3,4}$. We believe that large timbers may not have been necessary for statue building; in particular, we have shown that the Y-sledge and bipod hypothesized by Mulloy ${ }^{4}$ is not very efficient ${ }^{5}$.

The pollen records described by Flenley and King confirm Skottsberg's description of the island's impoverished biota as "waifs and strays"6. Only four of the identified genera of "probable trees and shrubs" became extinct on Easter Island before protohistoric times. Flenley and King identified Heliantheae, a tribe of primarily herbs and shrubs, and suggested Chrysogonum L. and Campylotheca Cass. as the probable genera. Some tree-like species do occur in Heliantheae but, because of its herbaceous origin, its wood character is immature and there is little development of secondary xylem ${ }^{7,8}$. Consequently, the wood is soft and porous. Tree-like species within Campylotheca are no taller than $\sim 2 \mathrm{~m}$, and within Oparanthus Sherff. (based on the former Chrysogonum sect. Quadramera F. Brown) there is only one known tree, Oparanthus rapense, which, although of medium size, is definitely soft ${ }^{9}$. The presence of another former genus, the putrid-smelling Coprosma, within the last few thousand years was indicated by only traces of pollen. Of its approximately 100 species of shrubs and trees ${ }^{10}$, useful timber can come only from a few of the largest. One can argue on biogeographical grounds that the Easter Island Coprosma probably represents a known or extinct species of the Pyrifolia group. However, all except possibly one are shrubs or small trees of limited or no practical value. The final missing species identified is palm, probably a Pritchardia. Some species of Pritchardia can grow to up to $20 \mathrm{~m}$, but $65 \%$ are less than $5 \mathrm{~m}$ in height (some are even smaller than $1 \mathrm{~m})^{11,12}$. The useful height of a palm is considerably less than its standing height ${ }^{13}$ and as palm wood is flexible its use as a lever or for shear legs is very limited. Palm logs could have served as rollers, but they are not particularly efficient when used on the ground or on a roughly constructed trackway, especially if they are of small diameter ${ }^{5}$. A further problem is that palm wood is not very durable-the trunks of nearly all species split on drying and, without preservatives, tend to $\operatorname{rot}^{13}$. We believe, therefore, that the trees and shrubs indicated by the pollen analysis cannot be clearly taken as a significant source of large timber suitable for moving the statues.

Flenley and King ${ }^{1,14}$ had a considerable problem in dating their pollen records and expressed reservations about 5 of their 13 ${ }^{14} \mathrm{C}$ dates. With a single exception, the suspected dates include those most relevant to prehistoric human occupation. Pollen from former genera continues into protohistoric and recent levels at all three sites, indicating a degree of sediment mixing which, at least in part, could have been caused by human activity in the crater and caldera lakes $^{15,16}$. At Rano Raraku, recent gulley erosion, reported elsewhere ${ }^{14}$, may also be responsible.

The Rano Kao core provides the most relevant data for the period of human habitation. However, the only two ${ }^{14} \mathrm{C}$ dates for this core are in conflict. Flenley and King rejected a date of $1,040 \pm 60 \mathrm{BP}$ from the middle of the core because of a drop in loss-on-ignition values. It is on the basis of the single ${ }^{14} \mathrm{C}$ date of $990 \pm 70 \mathrm{BP}$ at a depth of $\sim 9 \mathrm{~m}$ that Flenley and King argue for deforestation occurring at $\sim 500 \mathrm{BP}$. We think that it is premature to draw this conclusion without at least one other ${ }^{14} \mathrm{C}$ date as a check.

If large timbers were important they would have been required throughout the statue-building era, from $\sim \mathrm{AD} 1000$ to possibly as late as $1680^{17}$. The largest statue ever erected, the 80-tonne Paro, belongs late in the sequence, yet when Europeans arrived the longest piece of timber seen on the island was only a plank of a little over $2 \mathrm{~m}$ (refs 2,18 ). Could all large timber artefacts have completely disappeared in such a short interval?

Division of Prehistory,

JOHAN KAMMINGA

La Trobe University,

Bundoora, Victoria 3083,

Australia

\section{BRIAN COTTERELL}

Department of Mechanical Engineering,

University of Sydney,

New South Wales 2006,

Australia

1. Flenley, J. R. \& King, S. M. Nature 307, 47-50 (1984)

2. La Pérouse, J. F. de G. Voyage de la Pérouse Autour du Monde (Paris, 1797; Engl. transl.: Johnson, London, 1978).

3. Heyerdahi, T. Sea Routes to Polynesia (Allen \& Unwin, London, 1957).

4. Mulloy, W. J. Archaeol. phys. Anthrop. Oceania 5, 1-23 (1970).

5. Cotterell, B. \& Kamminga, J. Cultural Mechanics. An Introduction to the Mechanics of Early Technology (Penguin, London, in the press).

6. Skottsberg, C. The Natural History of Juan Fernandez and Easter Island Vol. 1, 193-438 (Almqvist \& Wiksells, Uppsala, 1956).

7. Carlquist, S. Trop. Woods 108, 1-30 (1958).

8. Carlquist, S. Aliso 6, 13-24 (1965)

9. Brown, F. B. H. Bermice P. Bishop Mus. Bull. 130 (1935). 10. Oliver, W. R. B. Bernice P. Bishop Mus. Bull. 132(1935).
11. Beccari, O. \& Rock, J. F. Bernice P. Bishop Mus. Mem. 8 (1921)

12. Caum, E. L., Bernice P. Bishop Mus. Occ. Pap. 9 (5) (1930). 13. McQuire, A. J. in Coconut Wood-1979. The Proceedings, 24-28 (Philippine Coconut Authority, Manila, 1979).

4. Flenley, J. R. Asian Perspect. 22, 33-40 (1979).

15. Metraux, A. Bernice P. Bishop Mus. Bull. 160 (1940).

15. Metraux, A. Bernice P. Bishop Mus. Bull. $160(1940)$.
16. McCoy, P. C. Easter Island Settlement Patterns in the Lat McCoy, P. C. Easter Island Settlement Patterns in the Late
Prehistoric and Protohistoric Periods (Easter Island Committee, International Fund for Monuments Inc., New York, 1976).

17. McCoy, P. C. The Prehistory of Polynesia (ed. Jennings, J. D.) 135-166 (Harvard University Press, Cambridge, Massachusetts, 1979).

18. Cook, J. A Voyage Towards the South Pole and Round the World (1772-75) Vol. 1, 2nd edn (Strahan \& Cadell, London, 1777).

FLENLEY AND KING REPLYKamminga and Cotterell appear to be taking issue with us on two main points: (1) whether the giant statues were moved with the aid of timber, and (2) the date of deforestation. As regards point (1), there is no issue to take. We did not conclude, even tentatively, that the statues were moved in any particular way, but merely that our results did not conflict with those of Mulloy ${ }^{1}$, who proposed the use of timber; the results are not conflicting. The pollen results show that Sophora and Palmae formerly grew on the island more abundantly than in the historic period. We have new evidence, which we hope to publish soon, that the palm was not a species of Pritchardia, so the indication by Kamminga and Cotterell that only $35 \%$ of Pritchardia species exceed $5 \mathrm{~m}$ height is irrelevant. As to how the statues were moved, we have no particular opinions.

On the subject of dating, we agree that there are problems. We believe the main reason for the reservations-the possibility of inwashed soil carbon-to be a reasonable one. If, however, the reservations are ignored, one would conclude that deforestation occurred after $6,850 \pm 60 \mathrm{BP}$ at Rano Raraku, after $2,100 \pm 50 \mathrm{BP}$ at Rano Aroi and both before and after $1,040 \pm 60$ at Rano Kao. These dates do not conflict with our tentative conclusions (Fig. 4 of ref. 2). As $1,040 \pm 60 \mathrm{BP}$ is not statistically separable from $990 \pm 70 \mathrm{BP}$, they do not even conflict with our statement that clearance occurred since $990 \pm$ $70 \mathrm{BP}$ at Rano Kao.

We all agree, I am sure, that more dates are desirable. These have now been obtained and will shortly be published. We agree that it is odd, if clearance was so late, that no very large wooden artefacts survived into historic times. It is worth noting, however, that Palmer in 1868 recorded "boles of large trees, Edwardsia (Sophora), Coco palm, hibiscus, decaying in some places"3. There would have been time for these species to have been introduced after the discovery of the island in 1722 , but the pollen record suggests that the Sophora and a palm were in fact native. It seems possible that Palmer's "Coco palm" was not coconut but the native 